\title{
Expert System for Diagnosis of Uterine Myomas Using the Certainty Factor Method
}

\author{
Syahrizal Dwi Putra*, M. Bahrul Ulum, Diah Aryani \\ Faculty of Computer Science, Universitas Esa Unggul, Indonesia \\ *Corresponding author E-mail: syahrizal.dwi@esaunggul.ac.id
}

\begin{abstract}
Manuscript received 15 August 2021; revised 1 Sept 2021; accepted 15 Sept 2021. Date of publication 4 Nov 2021

An expert system which is part of artificial intelligence is a computer system that is able to imitate the reasoning of an expert with certain expertise. An expert system in the form of software can replace the role of an expert (human) in the decision-making process based on the symptoms given to a certain level of certainty. This study raises the problem that many women experience, namely not understanding that they have uterine myomas. Many women do not understand and are not aware that there are already symptoms that are felt and these symptoms are symptoms of the presence of uterine myomas in their bodies. Therefore, it is necessary for women to be able to diagnose independently so that they can take treatment as quickly as possible. In this study, the expert will first provide the expert CF values. Then the user / respondent gives an assessment of his condition with the CF User values. In the end, the values obtained from these two factors will be processed using the certainty factor formula. Users must provide answers to all questions given by the system in accordance with their current conditions. After all the conditions asked are answered, the system will display the results to identify that the user is suffering from uterine myoma disease or not. The Expert System with the certainty factor method was tested with a patient who entered the symptoms experienced and got the percentage of confidence in uterine myomas/fibroids of $98.70 \%$. These results indicate that an expert system with the certainty factor method can be used to assist in diagnosing uterine myomas as early as possible.
\end{abstract}

Keywords: Disease diagnosis system, Expert System, Certainty Factor, Uterine Myomas

\section{Introduction}

Reproductive health problems in women can be said to be one of the important problems to get attention from all elements of society. So that health development is directed at improving the degree of public health, the quality of human resources, monitoring the reach of health services and the quality of health services life. In Indonesia as a developing country, there are about 25-50\% of deaths of women of childbearing age caused by problems related to pregnancy and childbirth as well as reproductive system diseases such as uterine myomas [1]. Uterine fibroids are the most common neoplasm in women and it has been postulated that they occur in more than $70 \%$ of women at the beginning of menopause [2].

A study conducted by [3] states that the incidence of reproductive disorders in developing countries reaches $36 \%$ of the total burden of illness suffered during the productive period. It is estimated that the incidence of uterine myoma is about $20 \%-35 \%$ of all women in the world[3].

The factors that cause uterine myomas/fibroids are not known for certain, but there are studies which state that a family history of the disease can be inherited genetically. The results of the analysis conducted at RSUD Prof. Dr. W. Z. Johannes Kupang showed a relationship between family history and the occurrence of uterine myomas/fibroids, including age of menarche and parity[4].

Classically the characteristics of uterine myomas /fibroids and uterine anatomy are considered to be almost unique problems in gynecology and reproductive medicine. Decisions by improving clinical diagnosis for this type of pathology, allow for improved personal care, as well as a reduction in potential risks and unnecessary surgery[5].

Uterine fibroids (leiomyomas or myomas), benign monoclonal tumors, are the most common benign tumors in women. Heavy or prolonged menstrual bleeding, abnormal uterine bleeding, resulting anemia, abdominal pain, infertility, and / or recurrent pregnancy loss are commonly associated with uterine fibroids[6]. Uterine fibroids are one of the most important female reproductive health problems for prevention. For this reason, it is necessary to know what causes uterine myomas so that all women can do early detection. Therefore, it is necessary to promote health so that preventable/modifiable risk factors can be minimized to reduce the chance of developing uterine myomas. 
Expert systems must be able to work in uncertainty. A number of theories have been found to resolve uncertainty, including the certainty factor. Certainty factor is a method to prove whether a fact is certain or uncertain in the form of a metric that is usually used in expert systems. This method is very suitable for expert systems that diagnose something that is not certain. The purpose of this study is to design an application for diagnosing uterine myomas with the certainty factor method to make it easier to determine whether a woman is suffering from uterine myoma based on the symptoms or complaints she experiences with the certainty factor method that has been made in this application.

\section{Literature Review}

Article [7] describes research with the method used is the Certainty Factor of ten diseases that can be diagnosed, namely haemorrhoids, nephrolithiasis, diabetes mellitus, hypertension, hepatitis, tuberculosis, bronchitis, sinusitis, gout, and rheumatism. The result of this research is a web-based expert system that is used to assist people in diagnosing diseases that can be cured by Bawang Dayak.

In research [8] describes gastritis which is divided into two, namely acute (develops quickly and suddenly) and chronic (developing slowly) with symptoms that often appear are pain, discomfort in the upper abdomen, nausea, vomiting, and indigestion. Most people do not understand the type of illness suffered because they do not have knowledge about that disease. Therefore, researchers recommend a system that can help people to be able to diagnose gastritis. The system used by the researcher is an expert system with certainty factor method. With this system, people who suffer from the symptoms of the disease and find it difficult to go to a hospital far from the home then can try this system to find out earlier before going to the doctor.

In the article [9] explains how certainty factors can be used in diagnosing dental and oral health. Periodontal disease is a gum disease caused by bacteria that damage the supporting tissues teeth and cause tooth loss. The certainty factor method used for calculations because the certainty factor method can solve the uncertainty of a problem by measuring one's beliefs. The result of this research is an expert system that can generate the name of the periodontal disease and the degree of certainty of the user's disease.

In addition, research [10] aims to develop system or software that can replace doctors for the identification process heart defects based on expert system. The expert system was developed with certainty factor with a double rule approach. In research [11], researchers make an android-based expert system application that can provide information to users about the disease that is being suffered through symptoms experienced by the user. Expert system creation processes the application uses a certainty factor method.

Based on previous research, it can be seen that expert systems with certainty factor methods can be used in diagnosing various diseases.

\section{Method}

Certainty factor is a belief in an event (fact or hypothesis) based on evidence or expert judgment. To get the level of confidence (CF) of a rule is obtained by interviewing an expert. The $\mathrm{CF}$ value (Rules) comes from the interpretation of the expert, which is converted to a certain CF value according to the following table I [7]:

Table 1. Certainty Factor Value And Interpretation

\begin{tabular}{cc}
\hline Uncertain Term & Value of CF \\
\hline Definitely not & -1.0 \\
\hline Almost certainly not & -0.8 \\
\hline Probably not & -0.6 \\
\hline Maybe not & -0.4 \\
\hline Unknown & -02 to 0.2 \\
\hline Maybe & 0.4 \\
\hline Probably & 0.6 \\
\hline Almost certainly & 0.8 \\
\hline Definitely & 1.0 \\
\hline
\end{tabular}

Table 1 above shows the Certainty factor using the value of an expert to assume a level of confidence in the data. The certainty factor is also used to determine the confidence value of the initial facts given by the users.

In the system to be built, identification of the users involved in this expert system has been carried out. In data processing and decision making for uterine myoma disease diagnosis, Certainty Factor has the following IF E THEN H rules[12]:

$\mathrm{CF}(\mathrm{H}, \mathrm{e})=\mathrm{CF}(\mathrm{E}, \mathrm{e}) * \mathrm{CF}(\mathrm{H}, \mathrm{E})$

CFcombineCF[H,E]1,2= CF[H,E]1 + CF[H,E $2 *[1-\mathrm{CF}[\mathrm{H}, \mathrm{E}] 1]$

CFcombineCF[H,E]old, $3=\mathrm{CF}[\mathrm{H}, \mathrm{E}]$ old $+\mathrm{CF}[\mathrm{H}, \mathrm{E}] 3 *(1-\mathrm{CF}[\mathrm{H}, \mathrm{E}]$ old $]$

Information:

$\mathrm{CF}(\mathrm{E}, \mathrm{e})=$ Certainty Factor $\mathrm{E}$ evidence that is influenced by evidence $\mathrm{e}$

$\mathrm{CF}(\mathrm{H}, \mathrm{E})=$ Certainty Factor hypothesis assuming evidence is known with certainty, namely when

$\mathrm{CF}(\mathrm{E}, \mathrm{e})=1$

$\mathrm{CF}(\mathrm{H}, \mathrm{e})=$ Certainty Factor hypothesis that is influenced by evidence $\mathrm{e}$

The following is a table of diseases consisting of uterine myomas and ovarian cysts. Ovarian cysts have some symptoms similar to uterine myomas/fibroids, so they are added for comparison. 
Table 2. Type of Disease

\begin{tabular}{lll}
\hline No & Disease Code & Disease Name \\
\hline $\mathbf{1}$ & P01 & Uterine Myomas/Fibroids \\
\hline $\mathbf{2}$ & P02 & Ovarian Cyst \\
\hline
\end{tabular}

Table 2 is the type of disease to be diagnosed. To determine the symptoms felt by the user or sufferer, a code is made for each of these symptoms as shown in the following table:

Table 3. Symptoms of Disease

\begin{tabular}{cl}
\hline Symptom Code & \multicolumn{1}{c}{ Symptom Name } \\
\hline S01 & Heavy menstrual bleeding \\
\hline S02 & Menstrual periods lasting more than a week \\
\hline S03 & Pelvic pressure or pain \\
\hline S04 & Frequent urination \\
\hline S05 & Difficulty emptying the bladder \\
\hline S06 & Constipation \\
\hline S07 & Backache \\
\hline S08 & Leg pains \\
\hline S09 & Pain during intercourse \\
\hline S10 & Infertility \\
\hline S11 & Miscarriage \\
\hline S12 & Discomfort in the lower abdomen \\
\hline S13 & Enlarged belly \\
\hline S14 & Menstrual disorders such as irregular menstrual periods \\
\hline S15 & Nausea and vomiting \\
\hline S16 & The stomach feels bloated \\
\hline S17 & Pain during sexual intercourse \\
\hline S18 & Back and thigh pain \\
\hline S19 & Pain in breast \\
\hline S20 & Fever \\
\hline S21 & Body feels weak \\
\hline S22 & Very annoying pelvic pain \\
\hline
\end{tabular}

Table 3 above is a table of symptoms of the disease that may be felt by the user or sufferer. These symptoms are symptoms that can occur in uterine myomas and or ovarian cysts.

Table 4: Rule Symptoms Table

\begin{tabular}{ccc}
\hline Symptom Code & P1 & P2 \\
\hline S01 & $X$ & \\
\hline S02 & $X$ & $X$ \\
\hline S03 & $X$ & \\
\hline S04 & $X$ & \\
\hline S05 & $X$ & \\
\hline S06 & $X$ & \\
\hline S07 & $X$ & \\
\hline S08 & $X$ & \\
\hline S09 & $X$ & \\
\hline S10 & $X$ & $X$ \\
\hline S11 & $X$ & \\
\hline S12 & $X$ & $X$ \\
\hline S13 & $X$ & $X$ \\
\hline S15 & $X$ & $X$ \\
\hline S16 & & $X$ \\
\hline S17 & & $X$ \\
\hline S18 & & $X$ \\
\hline S19 & & $X$ \\
\hline S20 & & $X$ \\
\hline S21 & &
\end{tabular}

Table 3 above is a table of symptoms of the disease that may be felt by the user or sufferer. These symptoms are symptoms that can occur in uterine myomas/fibroids and or ovarian cysts. 
Table 5: CF Expert Value

\begin{tabular}{cc}
\hline Symptom Code & CF Expert \\
\hline S01 & 0.4 \\
\hline S02 & 0.8 \\
\hline S03 & 0.8 \\
\hline S05 & 0.6 \\
\hline S06 & 0.6 \\
\hline S07 & 0.6 \\
\hline S08 & 0.6 \\
\hline S09 & 0.8 \\
\hline S10 & 0.6 \\
\hline S11 & 0.6 \\
\hline S12 & 0.4 \\
\hline S13 & 0.8 \\
\hline S14 & 0.8 \\
\hline S15 & 0.6 \\
\hline S16 & 0.4 \\
\hline S17 & 0.4 \\
\hline S18 & 0.6 \\
\hline S19 & 0.6 \\
\hline S20 & 0.6 \\
\hline S21 & 0.4 \\
\hline S22 & 0.6 \\
\hline
\end{tabular}

Table 3 above is a table of symptoms of the disease that may be felt by the user or sufferer. These symptoms are symptoms that can occur in uterine myomas and or ovarian cysts.

\section{Result and Discussion}

The following is an example of a known case of patient $\mathrm{x}$ who is 45 years old who wants to carry out a self-diagnosis process whether he suffers from uterine myoma with symptoms of the disease as follows: pelvic pain, leg pain, back pain, constipation, enlarged stomach size, frequent urination, menstrual period lasts more than a week.

Table 6. Table Example Case

\begin{tabular}{|c|c|c|c|}
\hline \multirow[t]{2}{*}{ No } & \multirow[t]{2}{*}{ Symptoms } & \multicolumn{2}{|c|}{ Disease } \\
\hline & & P1 & P2 \\
\hline 1 & Pelvic pain & S03 & \\
\hline 2 & Leg pain & S08 & \\
\hline 3 & Backache & S07 & \\
\hline 4 & Constipation & S06 & \\
\hline 5 & Enlarged belly & S13 & S13 \\
\hline 6 & Frequent urination & S04 & \\
\hline 7 & Menstrual periods lasting more than a week & S02 & S02 \\
\hline
\end{tabular}

Table 6 above is data from patients grouped by symptom code and possible disease.

Table 7. Patient X Symptom Input Data

\begin{tabular}{cccc}
\hline Symptom Code & CF User & CF Expert & Final CF (CF User x CF Expert) \\
\hline S03 & 0.8 & 0.8 & 0.64 \\
\hline S08 & 0.6 & 0.8 & 0.48 \\
S07 & 0.4 & 0.6 & 0.24 \\
\hline S06 & 0.6 & 0.6 & 0.36 \\
\hline S13 & 0.8 & 0.8 & 0.64 \\
\hline S04 & 0.4 & 0.6 & 0.24 \\
\hline S02 & 0.6 & 0.8 & 0.48 \\
\hline
\end{tabular}


Table 7 above is the next step is to change the patient's answer into a CF value (CF User) whose weight can be seen in table 7 below. After that the CF User value is multiplied by the CF expert value which will produce the final CF value. Based on the final CF value, the combined $\mathrm{CF}$ value is calculated based on equations (2) and (3).

CF Uterine Fibroids (P1) :

$\mathrm{CF}$ combineCF[H,E] $1,2=\mathrm{CF}[\mathrm{H}, \mathrm{E}] 1+\mathrm{CF}[\mathrm{H}, \mathrm{E}] 2 *[1-\mathrm{CF}[\mathrm{H}, \mathrm{E}] 1]=0+0.48(1-0)=0.48$

CFcombineCF[H,E]old,3=CF[H,E]old $+\mathrm{CF}[\mathrm{H}, \mathrm{E}] 3 *(1-\mathrm{CF}[\mathrm{H}, \mathrm{E}]$ old $]=0.48+0.64(1-0.48)=0.8128$

CFcombineCF[H,E]old,4=CF[H,E]old +CF[H,E] $4 *(1-\mathrm{CF}[\mathrm{H}, \mathrm{E}]$ old $]=0.8128+0.24(1-0.8128)=0.857728$

CFcombineCF[H,E]old,5=CF[H,E]old $+\mathrm{CF}[\mathrm{H}, \mathrm{E}] 5 *(1-\mathrm{CF}[\mathrm{H}, \mathrm{E}]$ old $]=0.857728+0(1-0.857728)=0.857728$

CFcombineCF[H,E]old,6=CF[H,E]old $+\mathrm{CF}[\mathrm{H}, \mathrm{E}] 6 *(1-\mathrm{CF}[\mathrm{H}, \mathrm{E}]$ old $]=0.857728+0,36(1-0.857728)=0.908946$

CFcombineCF[H,E]old,7=CF[H,E]old $+\mathrm{CF}[\mathrm{H}, \mathrm{E}] 7 *(1-\mathrm{CF}[\mathrm{H}, \mathrm{E}]$ old $]=0.908946+0,24(1-0.908946)=0.930799$

CFcombineCF[H,E]old, $8=\mathrm{CF}[\mathrm{H}, \mathrm{E}] \mathrm{old}+\mathrm{CF}[\mathrm{H}, \mathrm{E}] 8^{*}(1-\mathrm{CF}[\mathrm{H}, \mathrm{E}]$ old $]=0.930799+0,48(1-0.930799)=0.964015$

CFcombineCF[H,E]old,9=CF[H,E]old $+\mathrm{CF}[\mathrm{H}, \mathrm{E}] 9 *(1-\mathrm{CF}[\mathrm{H}, \mathrm{E}]$ old $]=0.964015+0(1-0.964015)=0.964015$

CFcombineCF[H,E]old, $10=\mathrm{CF}[\mathrm{H}, \mathrm{E}] \mathrm{old}+\mathrm{CF}[\mathrm{H}, \mathrm{E}] 10 *(1-\mathrm{CF}[\mathrm{H}, \mathrm{E}]$ old $]=0.964015+0(1-0.964015)=0.964015$

$\mathrm{CF}$ combineCF[H,E]old,11=CF[H,E]old $+\mathrm{CF}[\mathrm{H}, \mathrm{E}] 11 *(1-\mathrm{CF}[\mathrm{H}, \mathrm{E}]$ old $]=0.964015+0(1-0.964015)=0.964015$

$\mathrm{CF}$ combineCF[H,E]old,12=CF[H,E]old $+\mathrm{CF}[\mathrm{H}, \mathrm{E}] 12 *(1-\mathrm{CF}[\mathrm{H}, \mathrm{E}]$ old $]=0.964015+0(1-0.964015)=0.964015$

CFcombineCF[H,E]old,13=CF[H,E]old $+\mathrm{CF}[\mathrm{H}, \mathrm{E}] 13 *(1-\mathrm{CF}[\mathrm{H}, \mathrm{E}]$ old $]=0.964015+0.64(1-0.964015)=0.987046$

CFcombineCF[H,E]old,14=CF[H,E]old $+\mathrm{CF}[\mathrm{H}, \mathrm{E}] 14 *(1-\mathrm{CF}[\mathrm{H}, \mathrm{E}]$ old $]=0.987046+0(1-0.987046)=0.987046$

So, the percentage of confidence in uterine myoma/fibroid is: Confidence Percentage $=\mathrm{CF} * 100 \%=0.987046 * 100 \%=98,70 \%$

Based on the symptoms of the disease above, it can be concluded that the disease suffered by the patient was uterine myoma/fibroid with a percentage of $98.70 \%$. A diagnostic application that has been provided as a place for users to diagnose uterine myomas or ovarian cysts by selecting predetermined symptoms, so that conclusions will be made about the type of disease suffered.

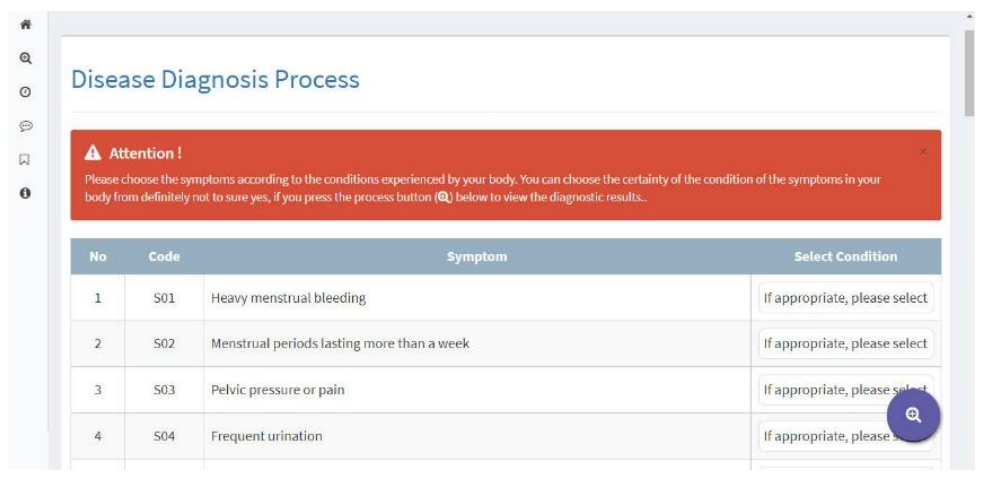

Fig 1. Disease diagnosis application form

\section{Conclusion}

The expert system with the certainty factor method has been tested on a patient who enters data on complaints or symptoms he feels. Then the results obtained are the percentage of confidence in uterine myomas/fibroids of $98.70 \%$. Based on the results obtained and the analysis carried out for the design of an expert system application with a certainty factor in diagnosing a person's illness, it can be concluded that the certainty factor method can make it easier to determine whether a woman has uterine myoma based on the symptoms or complaints she feels. 


\section{References}

[1] Tumaji, Rukmini, Oktarina, and N. Izza, "Pengaruh Riwayat Kesehatan Reproduksi terhadap Kejadian Mioma Uteri pada Perempuan di Perkotaan Indonesia," Buletin Penelitian Sistem Kesehatan, vol. 23, no. 2, pp. 89-98, 2020, doi: $10.22435 /$ hsr.v23i2.3238.

[2] E. Stewart, C. Cookson, R. Gandolfo, and R. Schulze-Rathc, "Epidemiology of uterine fibroids: a systematic review," BJOG: An International Journal of Obstetrics and Gynaecology, vol. 124, no. 10, pp. 1501-1512, Sep. 2017, doi: 10.1111/1471-0528.14730.

[3] A. A. Ekine, L. O. Lawani, C. A. Iyoke, I. Jeremiah, and I. A. Ibrahim, "Review of the Clinical Presentation of Uterine Fibroid and the Effect of Therapeutic Intervention on Fertility," American Journal of Clinical Medicine Research, vol. 3, no. 1, pp. 9-13, 2015, doi: 10.12691/ajcmr-3-1-2.

[4] I. Laning, I. Manurung, and A. Sir, "Faktor Risiko yang Berhubungan dengan Kejadian Penyakit Mioma Uteri," Lontar : Journal of Community Health, vol. 1, no. 3, pp. 95-102, 2019, doi: 10.35508/ljch.v1i3.2174.

[5] A. Mas, M. Tarazona, J. Dasí Carrasco, G. Estaca, I. Cristóbal, and J. Monleón, "Updated approaches for management of uterine fibroids," International Journal of Women's Health, vol. 9, pp. 607-617, Sep. 2017, doi: 10.2147/IJWH.S138982.

[6] G. S. Sohn, S. H. Cho, Y. M. Kim, C. H. Cho, M. R. Kim, and S. R. Lee, "Current medical treatment of uterine fibroids," Obstetrics and Gynecology Science, vol. 61, no. 2. Korean Society of Obstetrics and Gynecology, pp. 192-201, Mar. 01, 2018. doi: 10.5468/ogs.2018.61.2.192.

[7] J. A. Widians, N. Puspitasari, and A. Febriansyah, "Disease Diagnosis System Using Certainty Factor," in 2019 International Conference on Electrical, Electronics and Information Engineering (ICEEIE), 2019, pp. 303-308. doi: 10.1109/ICEEIE47180.2019.8981421.

[8] D. Adhar, Syafrizal, E. Panggabean, L. Sipahutar, and M. Reza Fahlevi, "Expert System to Diagnose Gastritis Disease Using the Certainty Factor Method," in 7th International Conference on Cyber and IT Service Management (CITSM), 2019, pp. 1-5. doi: 10.1109/CITSM47753.2019.8965363.

[9] Handrizal, E. M. Zamzami, and M. Arif, "Expert System in Periodontal Diseases Diagnosis Using the Certainty Factor Method," in Journal of Physics: Conference Series, Jun. 2021, vol. 1898, no. 1. doi: 10.1088/1742-6596/1898/1/012004.

[10] Sumiati, H. Saragih, T. K. A. Rahman, and A. Triayudi, "Expert system for heart disease based on electrocardiogram data using certainty factor with multiple rule," IAES International Journal of Artificial Intelligence, vol. 10, no. 1, pp. 43-50, 2021, doi: 10.11591/ijai.v10.i1.pp43-50.

[11] C. Kirana, H. A. Pradana, and R. Sulaiman, "Intestine Disease Diagnosis System Using Certainty Factor Method," Scientific Journal of Informatics, vol. 6, no. 1, pp. 2407-7658, 2019, [Online]. Available: http://journal.unnes.ac.id/nju/index.php/sji

[12] A. S. Sembiring et al., "Implementation of Certainty Factor Method for Expert System," in Journal of Physics: Conference Series, Sep. 2019, vol. 1255, no. 1. doi: 10.1088/1742-6596/1255/1/012065. 